\title{
Perlakuan Pupuk Kandang Untuk Mengurangi Dosis Pupuk Kimia Pada Budidaya Tanaman Cabai (Capsicum annuum L.)
}

\section{Manure Treatment to Reduce Chemical Fertlizer Dose in Chili (Capsicum annuum L.) Culture}

\author{
I Komang Damar Jaya*, Bambang Budi Santoso, Jayaputra \\ Kelompok Peneliti Bidang Ilmu Pertanian Lahan Kering, Fakultas Pertanian Universitas Mataram, \\ Nusa Tenggara Barat, INDONESIA. Tel. +62 370 621435, Fax: +62 370640189 \\ *corresponding author,email: ikdjaya@unram.ac.id
}

Manuscript received: 21-11-2021. Accepted: 22-12-2021

\begin{abstract}
ABSTRAK
Penggunaan pupuk kimia dosis tinggi dalam produksi cabai (Capsicum annuum L.) berdampak kurang baik terhadap lingkungan, khususnya di lahan kering. Penelitian ini bertujuan untuk mengkaji peran pupuk kandang sapi (PKS), pupuk kandang kambing (PKK), pupuk kandang ayam (PKA) atau kombinasi dua pupuk kandang dalam mengurangi 25\% kebutuhan pupuk kimia pada tanaman cabai. Satu percobaan dilaksanakan di lahan kering Desa Gumantar, Kabupaten Lombok Utara mulai bulan Mei sampai Oktober 2021. Pupuk kimia (PK) NPK (15-15-15) Phonska dengan dosis $1.200 \mathrm{~kg} / \mathrm{ha}$ digunakan sebagai kontrol. Perlakuan yang diuji adalah 75\% PK+PKS, 75\% PK+PKK, 75\% PK+PKA, 75\% PK+PKS+PKK, 75\% PK+PKS+PKA dan 75\% PK+PKK+PKA. Dosis pupuk kandang yang digunakan pada masing-masing perlakuan adalah 20 ton/ha. Semua perlakuan diulang tiga kali dan ditata dengan rancangan acak kelompok. Hasil penelitian menunjukkan bahwa perlakuan pupuk kandang, khususnya pupuk kandang kambing dan pupuk kandang ayam, mampu meningkatkan fosfat (P) tersedia di dalam tanah. Pertumbuhan dan hasil tanaman cabai tidak berbeda nyata pada semua perlakuan yang artinya, pupuk kandang mampu menggantikan peran 25\% dari pupuk kimia yang digunakan. Hasil ini mengindikasikan bahwa penggunaan pupuk kandang dalam jangka panjang dapat mengurangi kebutuhan pupuk kimia untuk memproduksi cabai di lahan kering.
\end{abstract}

Kata kunci: cabai; lahan kering; pupuk kandang; pupuk kimia; unsur hara

\begin{abstract}
The use of high doses of chemical fertilizers in the production of chili (Capsicum annuum L.) has an adverse impact on the environment, especially in dryland. This study aimed to examine the role of cow manure (PKS), goat manure (PKK), chicken manure (PKA), or a combination of two manures in reducing $25 \%$ of the requirement for chemical fertilizer on chili plants. One experiment was carried out in the dryland of Gumantar Village, North Lombok Regency, from May to October 2021. Phonska NPK (15-15-15) chemical fertilizer (PK) at a 1,200 kg/ha dose was used as a control. The treatments tested were $75 \% \mathrm{PK}+\mathrm{PKS}, 75 \% \mathrm{PK}+\mathrm{PKK}, 75 \% \mathrm{PK}+\mathrm{PKA}, 75 \% \mathrm{PK}+\mathrm{PKS}+\mathrm{PKK}, 75 \% \mathrm{PK}+\mathrm{PKS}+\mathrm{PKA}$ and $75 \% \mathrm{PK}+\mathrm{PKK}+\mathrm{PKA}$. The dose of manure used in each treatment was 20 tons/ha. All treatments were
\end{abstract}


repeated three times and arranged in a randomized block design. The results showed that the treatment of manure, especially goat manure and chicken manure, increased the available phosphate $(\mathrm{P})$ in the soil. The growth and yield of chili plants were not significantly different in all treatments, which means that manure could replace the role of $25 \%$ of the chemical fertilizer used. These results indicate that manure in the long term can reduce the need for chemical fertilizers to produce chili in dryland.

Key words: chili; dryland; manure; chemical fertilizer; nutrition

\section{PENDAHULUAN}

Cabai atau sering juga disebut dengan nama cabai merah (Capsicum annuum L.) merupakan salah satu komoditas hortikultura penting di Indonesia. Alasannya adalah karena cabai dikonsumsi oleh hampir semua penduduk Indonesia serta dalam pengusahaanya, mampu menyerap tenaga kerja yang cukup banyak. Cabai juga memiliki manfaat yang banyak bagi kesehatan manusia karena mengandung fitokimia, antoksidan dan mineral mikro, seperti asam folat, beta karoten, vitamin $\mathrm{A}$, vitamin $\mathrm{C}$, vitamin $\mathrm{E}$, mineral $\mathrm{Ca}, \mathrm{Fe}$ dan $\mathrm{Mg}$, sehingga sangat disarankan untuk mengkonsumsinya secara rutin (Kantar et al., 2016; Olatunji dan Afolayan, 2018). Harga cabai sangat berfluktuasi, tergantung pada musim tanam. Fluktuasi produksi dan harga cabai di Indonesia sering mengharuskan pemerintah untuk melakukan impor cabai dalam bentuk olahan kering. Mengimpor cabai tentunya tidak baik bagi bangsa Indonesia yang ingin mencapai kemerdekaan pangan. Selain itu, iklim yang dimiliki Indonesia juga sangat cocok untuk pertumbuhan tanaman cabai.

Tidak hanya produksi cabai yang berfluktuasi, konsumsi cabai juga berfluktuasi. Sebagai contoh, di tahun 2002 konsumsi cabai adalah 1,429 kg/kapita/tahun sedangkan tahun 2015 konsumsi cabai mencai 2,958 kg/kapita/tahun (Saida, 2019). Meskipun cabai dibutuhkan dalam jumlah yang relatif sedikit, namun karena jumlah penduduk Indonesia yang banyak, sekitar 170 juta jiwa, maka kebutuhan cabai secara nasional sangat tinggi. Data dari Badan Pusat Statistik (BPS, 2020) menunjukkan bahwa di Nusa Tenggara Barat (NTB) sendiri terjadi fluktuasi produksi cabai merah pada tahun 2018 dan 2019. Pada tahun 2018, produksi cabai merah NTB adalah 23,997 ton dan berkurang menjadi 17.679 ton pada tahun 2019. Dari segi produktivitas, juga terjadi penurunan sebesar 4,81\% pada tahun 2019 dibandingkan dengan tahun 2018. Pada tahun 2018 produktivitas cabai merah di NTB adalah 15,26 ton/ha sedangkan pada tahun 2019 hanya 10,45 ton/ha.

Produktivitas cabai merah yang hanya 10,45 ton/ha tentunya masih sangat rendah bila dibandingkan dengan potensi hasil dari varietas-varietas yang ada saat ini. Varietas Tanjung-2 misalnya, mempunyai potensi hasil sampai mencapai 19,9 ton/ha (http://www.litbang.pertanian.go.id/varietas/20/) dan varietas Ciko mem-punyai potensi hasil sampai 20,5 ton/ha (http://balitsa.litbang.pertanian.go.id/ ind/index.php/varietas/ cabai/36halaman/612-cabai-besar-varietas-ciko). Rendah-nya produktivitas cabai merah di NTB salah satunya disebabkan karena kurang optimalnya pupuk yang diberikan. Lahan pertanian di NTB, khususnya di lahan kering, kondisi ketersediaan unsur hara di dalam tanah sangat rendah (Jaya, 2021). Sementara itu, tanaman cabai membutuhkan unsur hara, khususnya kalium (dalam bentuk K2O) dalam jumlah yang banyak. Di lahan yang ketersediaan kaliumnya sedang, 
kebutuhan optimum K2O untuk produksi cabai besar yang optimal adalah 487,5 kg/ha (Widyanti dan Susila, 2015).

Selain membutuhkan biaya yang tinggi, penggunaan pupuk kimia dalam jumlah yang banyak secara terus-menerus juga berdampak negatif terhadap lahan dan lingkungan, khususnya hubungan antara mikroba dan tanaman (Huang et al., 2019). Oleh karena itu, penggunaan pupuk kimia harus dikurangi dan efisiensinya harus ditingkatkan untuk dapat memproduksi cabai secara optimal dan berkelanjutan. Salah satu cara untuk meningkatkan kualitas lahan dan hasil tanaman cabai adalah dengan menambahkan bahan organik, seperti kompos dan kotoran ayam (Rudisill et al., 2015; Wang et al., 2015). Selain bahan organik yang berasal dari kotoran ayam (pupuk kandang ayam), bahan organik yang berasal dari pupuk kandang sapi dan pupuk kandang kambing juga dilaporkan dapat meningkatkan hasil tanaman dan memperbaiki kualitas lahan (Jiang et al., 2019; Mabuza et al., 2019).

Penggunaan pupuk kandang dapat meningkatkan efisiensi penggunaan nitrogen dan air oleh tanaman (Rehim et al., 2020; Zhang et al., 2017). Ada beberapa jenis pupuk kandang yang dihasilkan oleh keluarga petani di lahan kering, seperti pupuk kandang sapi, pupuk kandang ayam dan pupuk kandang kambing. Namun sering kali mereka tidak memiliki jumlah pupuk kandang yang cukup yang berasal dari satu jenis hewan atau ternak. Oleh karena itu, petani cukup sering mencampur pupuk kandang yang berbeda untuk diaplikasikan pada lahan. Hasil penelitian Reddy et al. (2017) menunjukkan bahwa kombinasi tertentu dari pupuk organik dapat memperbaiki pertumbuhan dan hasil tanaman cabai. Penemuan itu membuka peluang untuk mencoba kombinasi pupuk kandang untuk meningkatkan hasil tanaman cabai dan mengurangi penggunaan pupuk kimia di lahan kering. Penelitian ini bertujuan untuk mengkaji potensi pengurangan dosis pupuk kimia sebesar $25 \%$ dengan aplikasi beberapa jenis pupuk kandang pada tanaman cabai di lahan kering.

\section{BAHAN DAN METODE}

\section{Waktu, Kondisi, dan Tempat Percobaan}

Penelitian ini menggunakan metoda eksperimental dengan satu percobaan di lahan kering milik petani di Dusun Amor-amor, Desa Gumantar, Kecamatan Kayangan, Kabupaten Lombok Utara, Nusa Tenggara Barat (8,253654 S, 116,285695 T). Tekstur tanah di lokasi percobaan adalah pasiran dengan tipe tanah Entisol. Kandungan nitrogen dan bahan organik tanah sangat rendah, fospat dan kalium tersedia tergolong sedang sampai tinggi (Jaya, 2021). Percobaan dimulai dari bulan Mei sampai September 2021. Suhu udara di lokasi percobaan dari bulan Mei sampai Oktober 2021 berkisar antara $24^{\circ} \mathrm{C}$ sampai dengan $35^{\circ} \mathrm{C}$ dengan kelembaban udara berkisar $50 \%$ sampai $97 \%$. Curah hujan yang diterima selama percobaan adalah $58 \mathrm{~mm}$ dengan delapan hari hujan. Kebutuhan air tanaman secara umum dipenuhi dari air yang dipompa dari sumur pompa dalam yang ada di sekitar lokasi percobaan.

\section{Perlakuan dan Desain Percobaan}

Pupuk kandang yang diuji adalah pupuk kandang sapi (PKS), pupuk kandang kambing (PKK) dan pupuk kandang ayam (PKA). Pada penelitian ini, pengurangan dosis pupuk kimia (PK) yang diuji adalah sebesar 25\% dari dosis $1.140 \mathrm{~kg}$ NPK Phonska yang umum digunakan oleh petani. Perlakuan-perlakuan yang diuji adalah sebagai berikut: (A). PK 100\%, (B). PK 
75\% + PKS, (C). PK 75\% + PKK, (D). PK 75\% + PKA, (E) PK 75\% + PKS + PKK, (F). PK $75 \%+\mathrm{PKS}+\mathrm{PKA}$ dan $(\mathrm{G}) . \mathrm{PK} 75 \%+\mathrm{PKK}+\mathrm{PKA}$.

Dosis pupuk kimia 100\% yang dimaksud adalah $1.140 \mathrm{~kg}$ NPK (15-15-15) Phonska per hektar dan dosis perlakuan pupuk kandang per hektar adalah 20 ton. Jika ada dua jenis pupuk kandang yang diperlakukan, tiap-tiap jenis pupuk kandang dosisnya adalah 10 ton/ha.

Semua perlakuan ditata dengan Rancangan Acak Kelompok (RAK) menggunakan tiga ulangan sehingga terdapat 21 plot perlakuan. Pada masing-masing plot perlakuan terdapat 20 tanaman dan tiga tanaman per perlakuan dijadikan sebagai tanaman sampel.

\section{Tatalaksana Percobaan dan Pengamatan}

Dibuat sebanyak 21 plot percobaan sesuai dengan jumlah perlakuan. Ukuran panjang masing-masing plot adalah $600 \mathrm{~cm}$ dengan lebar permukaan atas $80 \mathrm{~cm}$, permukaan bawah 100 $\mathrm{cm}$ dan tinggi $30 \mathrm{~cm}$. Plot-plot perlakuan ditaburi pupuk kandang sesuai dengan perlakuan dan dicampur rata dengan tanah. Tiga minggu setelah pupuk kandang diaplikasikan, pupuk NPK Phonska diaplikasikan di bagian tengah plot sebagai pupuk dasar dengan dosis $700 \mathrm{~kg} / \mathrm{ha}$. Mulsa plastik dipasang pada setiap plot perlakuan dan selanjutnya dibuat lubang tanam. Dalam satu plot dibuat 20 lubang tanam dengan jarak 60 x $60 \mathrm{~cm}$. Bibit cabai yang ditanam telah melalui proses penyemaian selama 28 hari dan telah memiliki empat helai daun.

Aplikasi pupuk kimia susulan dilakukan tiga kali, yaitu pada umur 15 hari setelah tanam (HST) dengan dosis $80 \mathrm{~kg} / \mathrm{ha}$, umur 35 HST dengan dosis $120 \mathrm{~kg} / \mathrm{ha}$ dan umur 56 HST dengan dosis $240 \mathrm{~kg} / \mathrm{ha}$. Pengariran dilakukan secara rutin dan tergantung dari kondisi tanaman di lapang.

\section{Observasi dan Data Analisis}

Beberapa parameter sifat kimia tanah, seperti total nitrogen $(\mathrm{N})$, fosfat $(\mathrm{P})$ dan kalium (K) tersedia, C-organik, dan $\mathrm{pH}$ tanah dianalisis di Laboratorium Pengujian BPTP NTB. Sampel tanah diambil sehari sebelum pupuk dasar NPK Phonska diaplikasikan pada masingmasing plot perlakuan. Kandungan N, P dan $\mathrm{K}$ di dalam jaringan tanaman dianalisa di Laboratorium Kimia Tanah, Fakultas Pertanian Universitas Mataram. Sampel tanaman diambil saat tanaman mulai memasuki fase generatif, yaitu 30 hari setelah tanam (HST).

Variable pertumbuhan, perkembangan dan hasil tanaman yang diamati adalah tinggi tanaman, jumlah daun, jumlah cabang produktif (saat panen pertama), jumlah bunga per tanaman, jumlah buah per tanaman, berat buah per tanaman dan berat buah per petak. Panen terakhir dilakukan ketika tanaman sudah berumur 120 HST. Data hasil pengamatan dianalisis menggunakan Analysis of Variance (Anova) pada taraf nyata 5\%. Uji lanjut dengan Duncan Multiple Range Test (DMRT) pada taraf 5\% dilakukan pada perlakuan-perlakuan yang menunjukkan pengaruh yang nyata dari hasil Anova.

\section{HASIL DAN PEMBAHASAN}

\section{Gambaran Umum Tentang Hasil Percobaan}

Terjadi serangan hama lalat buah (Bactrocera cucurbitae) ketika tanaman mulai memasuki fase pemasakan buah. Intensitas serangan lalat buah ini cukup tinggi sehingga mengakibatkan buah membusuk dan gugur dengan persentase mencapai 26\%. Pada perioda pemasakan buah juga terjadi serangan penyakit antraknosa yang disebabkan oleh jamur 
Colletotricum capsica, namun tingkat serangan tidak begitu signifikan. Dengan banyaknya buah yang gugur dan sangat berpotensi mempengaruhi hasil penelitian maka pengamatan dihentikan setelah panen kelima, yaitu 120 HST.

\section{Pengaruh Perlakuan Terhadap Sifat Kimia Tanah}

Perlakuan berbagai jenis pupuk kandang dan kombinasinya berpengaruh terhadap beberapa parameter sifat kimia tanah (Tabel 1). Tingkat kemasaman $(\mathrm{pH})$ tanah di lokasi percobaan tergolong netral, yaitu sebesar 6,69. Aplikasi pupuk kandang, selain pupuk kandang ayam, berdampak pada penurunan $\mathrm{pH}$ tanah sampai mencapai 6,30. Sementara itu, perlakuan pupuk kandang ayam tidak merubah $\mathrm{pH}$ tanah. Hal ini bisa dimaklumi karena kotoran ayam mengandung kalsium $(\mathrm{Ca})$ yang tinggi sebagai bagian dari pakan ayam (Naramabuye dan Haynes, 2006). Pupuk kandang lainnya, selain pupuk kandang ayam menurunkan $\mathrm{pH}$ tanah karena kandungan bahan organik yang dikandungnya mampu meningkatkan kemampuan tanah mengikat air. Akibatnya, $\mathrm{pH}$ tanah cenderung menurun ke arah asam, namun masih pada kisaran optimum untuk pertumbuhan tanaman cabai.

Tabel 1. Pengaruh perlakuan beberapa jenis pupuk kandang terhadap beberapa sifat kimia tanah di plot-plot percobaan sebelum dilakukan pindah tanam

\begin{tabular}{lccccc}
\hline & \multicolumn{4}{c}{ Variabel yang diamati } \\
\cline { 2 - 6 } Perlakuan & $\mathrm{pH}$ & $\begin{array}{c}\mathrm{C}- \\
\text { Organik } \\
(\%)\end{array}$ & $\begin{array}{c}\mathrm{N} \\
\text { Total } \\
(\%)\end{array}$ & $\begin{array}{c}\mathrm{P} \\
\text { tersedia. } \\
(\mathrm{ppm})\end{array}$ & $\begin{array}{c}\mathrm{K} \\
\text { tersedia. } \\
(\mathrm{ppm})\end{array}$ \\
\hline $\mathrm{A}(100 \%$ PK) & $6.69 \mathrm{e}^{*}$ & 0.93 & 0.06 & $11.45 \mathrm{a}$ & 74.00 \\
$\mathrm{~B}(75 \%$ PK+PKS) & $6.44 \mathrm{bc}$ & 0.93 & 0.07 & $24.76 \mathrm{ab}$ & 78.74 \\
$\mathrm{C}(75 \%$ PK+PKK) & $6.52 \mathrm{~cd}$ & 1.38 & 0.11 & $57.02 \mathrm{c}$ & 81.66 \\
$\mathrm{D}(75 \%$ PK+PKA) & $6.64 \mathrm{de}$ & 1.02 & 0.05 & $61.48 \mathrm{c}$ & 76.83 \\
E (75\% PK+PKS+PKK) & $6.30 \mathrm{a}$ & 1.21 & 0.04 & $28.38 \mathrm{~b}$ & 74.07 \\
F (75\% PK+PKS+PKA) & $6.37 \mathrm{ab}$ & 0.98 & 0.04 & $53.23 \mathrm{c}$ & 79.09 \\
G (75\% PK+PKK+PKA) & $6.35 \mathrm{ab}$ & 1.13 & 0.06 & $58.45 \mathrm{c}$ & 72.58 \\
\hline Kenyyyyyy
\end{tabular}

Keterangan: * angka-angka yang diikuti oleh huruf yang sama berbeda tidak nyata menurut uji DMRT pada taraf 5\%. PK= pupuk kimia NPK, PKS= pupuk kandang sapi, $\mathrm{PKK}=$ pupuk kandang kambing dan PKA= pupuk kandang ayam.

Sifat kimia tanah lainnya yang dipengaruhi oleh perlakuan beberapa jenis pupuk kandang dan kombinasinya adalah kandungan $\mathrm{P}$ tersedia di dalam tanah. Hasil analisis menunjukkan bahwa pupuk kandang ayam dan pupuk kandang kambing atau kombinasinya, mampu meningkatkan kandungan $\mathrm{P}$ tersedia di dalam tanah (Tabel 1). Hasil ini sejalan dengan penelitian sebelumnya bahwa pupuk kandang kambing dan pupuk kandang ayam mengandung P lebih banyak dari pupuk kandang sapi (Azeez dan van Averbeke, 2010). Pada perlakuan kontrol (100\% pupuk kimia, tetapi sampel diambil sebelum pupuk kimia diaplikasikan), harkat kandungan P tersedia di dalam tanah tergolong sedang (Eviati dan Sulaeman, 2009). Harkat kandungan $\mathrm{P}$ tersedia pada perlakuan dengan pupuk kandang masuk katagori sangat tinggi, meskipun pada perlakuan pupuk kandang sapi harkatnya tidak berbeda nyata dengan perlakuan kontrol (100\% pupuk kimia). 
Sementara itu, aplikasi pupuk kandang, baik secara individu maupun kombinasi, belum mampu meningkatkan kandungan $\mathrm{N}$ total, $\mathrm{C}$-organik, dan $\mathrm{K}$ tersedia di dalam tanah. Kandungan C-organik di dalam tanah pada semua perlakuan masuk dalam harkat sangat rendah sampai rendah, sementara kandungan $\mathrm{N}$ di dalam tanah pada semua perlakuan masuk dalam harkat sangat rendah (Eviati dan Sulaeman, 2009). Ada kemungkinan bahwa pada saat pengambilan sampel tanah (tiga minggu setelah aplikasi pupuk kandang), mikroba yang ada di dalam pupuk kandang masih aktif dalam melakukan proses dekomposisi sehingga memanfaatkan kandungan nitrogen yang ada di dalamnya (Korsaeth et al., 2002). Dalam hal kandungan $\mathrm{K}$ tersedia, harkatnya masuk katagori sangat tinggi pada semua perlakuan. Hal ini berarti tanah di lokasi percobaan sudah mengandung hara $\mathrm{K}$ dalam harkat yang sangat tinggi. Penambahan berbagai jenis pupuk kandang tidak berpengaruh terhadap kandungan $\mathrm{K}$ tanah karena pupuk kandang mengandung $\mathrm{K}$ yang lebih rendah dari P (Azeez dan van Averbeke, 2010).

\section{Pengaruh Perlakuan Terhadap Pertumbuhan dan Jumlah Bunga}

Pertumbuhan tanaman cabai yang meliputi tinggi tanaman dan jumlah daun saat panen pertama tidak dipengaruhi oleh perlakuan. Demikian juga dengan jumlah bunga, tidak dipengaruhi oleh perlakuan, namun perlakuan berpengaruh terhadap diameter batang (Tabel 2). Fakta ini menunjukkan bahwa peran $25 \%$ dari pupuk anorganik NPK Phonska dapat digantikan oleh berbagai jenis pupuk kandang.

Tabel 2. Pengaruh perlakuan beberapa jenis pupuk kandang terhadap variabel pertumbuhan tanaman saat panen pertama dan jumlah bunga

\begin{tabular}{lcccc}
\hline \multirow{2}{*}{ Perlakuan } & \multicolumn{4}{c}{ Variabel yang diamati } \\
\cline { 2 - 5 } & $\begin{array}{c}\text { Tinggi } \\
\text { Tanaman } \\
(\mathrm{cm})\end{array}$ & Jumlah daun & $\begin{array}{c}\text { Diameter } \\
\text { batang } \\
(\mathrm{mm})\end{array}$ & $\begin{array}{c}\text { Jumlah } \\
\text { bunga }\end{array}$ \\
\hline A (100\% PK) & 82.0 & 102.7 & $15.4 \mathrm{~d}^{*}$ & 76.1 \\
B (75\% PK+PKS)) & 77.4 & 87.2 & $13.3 \mathrm{ab}$ & 72.6 \\
C (75\% PK+PKK) & 83.9 & 110.5 & $14.7 \mathrm{~cd}$ & 88.0 \\
D (75\% PK+PKA) & 85.9 & 106.9 & $13.4 \mathrm{ab}$ & 81.6 \\
E (75\% PK+PKS+PKK) & 80.5 & 70.5 & $13.2 \mathrm{a}$ & 69.9 \\
F (75\% PK+PKS+PKA) & 86.5 & 95.6 & $14.4 \mathrm{c}$ & 78.0 \\
G (75\% PK+PKK+PKA) & 83.8 & 118.8 & $14.1 \mathrm{bc}$ & 80.1 \\
\hline
\end{tabular}

Keterangan: * angka-angka yang diikuti oleh huruf yang sama berbeda tidak nyata menurut uji DMRT pada taraf 5\%. PK= pupuk kimia NPK, PKS= pupuk kandang sapi, PKK= pupuk kandang kambing dan PKA= pupuk kandang ayam.

Seperti terlihat pada Tabel 1 bahwa pupuk kandang mampu meningkatkan kandungan unsur P di dalam tanah secara sigifikan. Selain itu, sudah menjadi pengetahuan umum bahwa pupuk kandang mampu meningkatkan serapan unsur hara bagi tanaman serta dapat meningkatkan efisiensi penggunaan nitrogen dan air (Prasad et al., 2017; Rehim et al., 2020; Zhang et al., 2017) sehingga pertumbuhan tanaman menjadi lebih baik. 
Perlakuan yang berbeda nyata hanya ditemukan pada diameter batang pada saat panen pertama. Diameter tertinggi dihasilkan dari perlakuan 100\% pupuk kimia dan berbeda nyata dengan semua perlakuan lainnya. Hal ini wajar karena pupuk kimia menyediakan unsur hara jauh lebih awal dari pupuk kandang, khususnya unsur $\mathrm{K}$ yang sangat berperan dalam menentukan ukuran diameter batang (Ajirloo et al., 2015). Dalam hal jumlah bunga, tidak ada perbedaan yang nyata antara perlakuan $100 \%$ pupuk kimia dengan perlakuan yang lainnya. Jumlah bunga banyak dipengaruhi oleh unsur fospor $(\mathrm{P})$ dan tambahan fosfor dari pupuk kandang mampu menggantikan $25 \%$ pengurangan fosfor dari pupuk kimia.

\section{Pengaruh Perlakuan Terhadap Kandungan N, P dan K dalam Jaringan dan Persentase Gugur} Bunga

Kandungan nitrogen $(\mathrm{N})$, fospor $(\mathrm{P})$ dan kalium $(\mathrm{K})$ di dalam jaringan tanaman pada akhir fase vegetatif tidak dipengaruhi oleh perlakuan, demikian juga dengan persentase bunga yang gugur (Tabel 3). Data pada Tabel 3 kembali menunjukkan bahwa jika pupuk kimia, dalam hal ini NPK Phonska dikurangi 25\% dan digantikan dengan berbagai pupuk kandang dengan dosis 20 ton/ha, maka tidak akan mempengaruhi serapan unsur hara oleh tanaman cabai. Alasannya adalah karena unsur hara tersedia cukup di dalam tanah (Tabel 1) dan kemampuan tanaman menyerap unsur hara juga meningkat sebagai akibat perlakuan pupuk kandang (Prasad et al., 2017).

Tabel 3. Pengaruh perlakuan beberapa jenis pupuk kandang terhadap kandungan $\mathrm{N}, \mathrm{P}$ dan $\mathrm{K}$ jaringan tanaman cabai dan persentase bunga yang gugur

\begin{tabular}{lcccc}
\hline \multirow{2}{*}{ Treatments } & \multicolumn{4}{c}{ Variabel yang diamati } \\
\cline { 2 - 5 } & $\begin{array}{c}\text { N total } \\
\text { jaringan }(\%)\end{array}$ & $\begin{array}{c}\text { P total } \\
\text { jaringan } \\
(\%)\end{array}$ & $\begin{array}{c}\text { K total } \\
\text { jaringan } \\
(\%)\end{array}$ & $\begin{array}{c}\text { Bunga } \\
\text { gugur (\%) }\end{array}$ \\
\hline A (100\% PK) & 4.88 & 0.42 & 1.93 & 15.1 \\
B (75\% PK+PKS)) & 5.29 & 0.42 & 2.01 & 14.9 \\
C (75\% PK+PKK) & 4.84 & 0.41 & 2.01 & 14.5 \\
D (75\% PK+PKA) & 4.68 & 0.40 & 1.69 & 15.2 \\
E (75\% PK+PKS+PKK) & 5.32 & 0.44 & 2.00 & 17.3 \\
F (75\% PK+PKS+PKA) & 4.62 & 0.40 & 2.04 & 17.1 \\
G (75\% PK+PKK+PKA) & 4.72 & 0.40 & 1.98 & 14.0 \\
\hline
\end{tabular}

Keterangan: $\mathrm{PK}=$ pupuk kimia $\mathrm{NPK}, \mathrm{PKS}=$ pupuk kandang sapi, $\mathrm{PKK}=$ pupuk kandang kambing dan $\mathrm{PKA}=$ pupuk kandang ayam.

Kalium (K) memegang peranan penting dalam proses pembuahan. Kandungan kalium yang rendah pada tanaman cabai saat proses pembuahan dapat mengakibatkan bunga-bunga tanaman cabai gugur (Pampuro et al., 2017). Jika dilihat dari Tabel 3, persentase bunga cabai yang gugur berkisar antara 14 sampai 17\%. Nilai ini cukup tinggi dan ada dua kemungkinan penyebabnya. Pertama, karena jumlah bunga yang terlalu banyak sehingga tanaman tidak mampu mendukung pembentukan buah dari seluruh bunga yang terbentuk (asimilat yang dihasilkan tanaman kurang) atau yang kedua, karena tanaman kekurangan nutrisi khususnya kalium. Jika dilihat dari kandungan $\mathrm{K}$ tanah sebelum pindah tanam (Tabel 1), semua perlakuan 
memiliki harkat $\mathrm{K}$ tersedia sangat tinggi. Kandungan kalium di dalam jaringan tanaman juga tidak berbeda nyata pada semua perlakuan (Tabel 3) sehingga persentase bunga yang gugur juga tidak berbeda nyata. Berdasarkan fakta-fakta yang sudah disampaikan, penyebab utama gugur bunga yang mencapai $17 \%$ kemungkinannya adalah karena jumlah bunga yang terlalu banyak.

\section{Pengaruh Perlakuan Terhadap Hasil dan Komponen Hasil Tanaman}

Hasil dan komponen hasil tanaman cabai merah tidak dipengaruhi oleh perlakuan (Tabel 4). Seperti disampaikan sebelumnya, hasil tanaman yang dilaporkan dalam penelitian ini hanya sampai 120 HST atau lima kali panen. Hasil tanaman cabai yang dilaporkan juga tidak terlepas dari pengaruh serangan lalat buah yang sudah disampaikan sebelumnya. Namun jika melihat data komponen hasil tanaman, seperti panjang buah yang menentukan berat buah, tidak terlihat adanya pengaruh perlakuan terhadap parameter ini (Tabel 4). Hal ini dimungkinkan karena tidak ada perbedaan kandungan $\mathrm{N}, \mathrm{P}$ dan $\mathrm{K}$ di dalam jaringan tanaman pada saat tanaman memasuki fase generatif (Tabel 3). Pernyataan ini sejalan dengan penelitian sebelumnya yang menunjukkan bahwa unsur hara $\mathrm{N}, \mathrm{P}$ dan $\mathrm{K}$ sangat menentukan hasil dan komponen hasil tanaman cabai (Ahmed and Abdelkader, 2020).

Tabel 4. Pengaruh perlakuan terhadap hasil dan komponen hasil tanaman cabai merah.

\begin{tabular}{lcccc}
\hline \multirow{2}{*}{ Perlakuan } & \multicolumn{4}{c}{ Variabel yang diamati } \\
\cline { 2 - 5 } & $\begin{array}{c}\text { Jumlah } \\
\text { buah per } \\
\text { tanaman }\end{array}$ & $\begin{array}{c}\text { Panjang } \\
\text { buah }(\mathrm{cm})\end{array}$ & $\begin{array}{c}\text { Berat buah } \\
\text { per tanaman } \\
(\mathrm{g})\end{array}$ & $\begin{array}{c}\text { Berat } \\
\text { buah per } \\
\text { plot }(\mathrm{kg})\end{array}$ \\
\hline A (100\% PK) & 31.2 & 10.4 & 284.4 & 6.36 \\
B (75\% PK+PKS)) & 32.2 & 10.9 & 297.2 & 6.54 \\
C (75\% PK+PKK) & 37.1 & 10.4 & 314.5 & 7.46 \\
D (75\% PK+PKA) & 36.7 & 10.4 & 306.6 & 6.83 \\
E (75\% PK+PKS+PKK) & 35.5 & 9.9 & 311.1 & 7.18 \\
F (75\% PK+PKS+PKA) & 33.5 & 10.8 & 293.8 & 6.88 \\
G (75\% PK+PKK+PKA) & 33.1 & 10.3 & 284.4 & 6.18 \\
\hline
\end{tabular}

Keterangan: $\mathrm{PK}=$ pupuk kimia NPK, $\mathrm{PKS}=$ pupuk kandang sapi, $\mathrm{PKK}=$ pupuk kandang kambing dan $\mathrm{PKA}=$ pupuk kandang ayam.

Data pada Tabel 4 menunjukkan bahwa semua pupuk kandang yang diuji pada penelitian ini, baik secara individu maupun ketika dikombinasikan, dapat menggantikan $25 \%$ peran pupuk anorganik NPK Phonska dalam budidaya tanaman cabai merah. Dengan demikian dapat dikatakan bahwa penggunaan pupuk kandang, baik secara individu maupun dikombinasikan dapat meningkatkan efisiensi pemupukan pupuk kimia NPK Phonska. Namun penggantian 25\% pupuk kimia NPK Phonska dengan berbagai jenis pupuk kandang dan kombinasinya belum mampu meningkatkan hasil tanaman cabai, seperti terlihat pada Tabel 4.

\section{KESIMPULAN}

Pada budidaya tanaman cabai, penggunaan pupuk kandang sapi, pupuk kandang kambing dan pupuk kandang ayam atau kombinasi dari dua pupuk kandang tersebut dengan dosis 20 ton/ha, dapat mengurangi dosis pupuk kimia NPK Phonska sebanyak 25\%. Aplikasi pupuk kandang pada lahan kering pasiran dapat meningkatkan kandungan unsur hara tanah, 
khususnya $\mathrm{P}$ yang sangat berperan dalam proses pembungaan dan pembuahan. Akan tetapi, peningkatan unsur hara tanah yang terjadi sebagai akibat aplikasi pupuk kandang belum mampu meningkatkan hasil tanaman cabai. Oleh karena itu, kegiatan penggunaan pupuk kandang di lahan kering pasiran untuk budidaya tanaman cabai masih perlu untuk diteruskan agar perbaikan sifat kimia tanah terus terjadi, dan diharapkan dapat diikuti oleh perbaikan sifat biologi dan fisika tanahnya.

\section{Ucapan Terimakasih}

Peneliti mengucapkan terima kasih kepada Universitas Mataram atas dana yang diberikan melalui penelitian skim Penelitian Peningkatan Kapasitas tahun 2021 dengan nomor kontrak 2956/UN18.L1/PP/2021.

\section{DAFTAR PUSTAKA}

Ahmed, M.A. and Abdelkader, M.A.I., 2020. Enhancing growth, yield components and chemical constituents of chilli (Capsicum annuum L.) plants by using different NPK fertilization levels and nano-micronutrients rates. Asian Journal of Soil Science and Plant Nutrition 6: 17-29.

Ajirloo, A.R., Shaaban, M., Motlagh, Z.R., 2015. Effect of K nano-fertilizer and N bio-fertilizer on yield and yield components of tomato (Lycopersicon esculentum L.). Int. J. Adv. Biol. Biom. Res. 3: 138-143.

Azeez, J.O., van Averbeke, W., 2010. Nitrogen mineralization potential of three animal manures applied on a sandy clay loam soil. Bioresour. Technol. 101:5645-51.

BPS, 2020. Luas Panen Tanaman Sayuran Menurut Provinsi dan Jenis Tanaman, 2020. https://www.bps.go.id/indikator/indikator/view_data_pub/0000/api_ pub/bXNVb1pmZndqUDhKWEIUSjhZRitidz09/da_05/1 (Diakses 10 Februari 2021)

Evianti dan Sulaeman, 2009. Analisis Kimia Tanah, Tanaman, Air, dan Pupuk. Petunjuk Teknis Edisi 2. Editor: B.H. Prasetyo, D. Santoso dan L. Retno W. Balai Penelitian Tanah, Bogor. 234 hal.

Huang, R., McGrath, S.P., Hirsch, P.R., Clark, I.M., Storkey, J., Wu, L., Zhou, J., and Liang, Y., 2019. Plant-microbe networks in soil are weakened by century-long use of inorganic fertilizers. Microbial Biotechnology 12: 1464-1475.

Jaya, I K. D., 2021. Cropping strategy in dryland areas with a high rainfall variability: a study from maize farmers in North Lombok, Indonesia. Journal of Agriculture Food and Development 7: 25-31.

Jiang, Y., Arafat, Y., Letuma, P., Ali, L., Tayyab, M., Waqas, M., Li, Y., Lin, W., Lin, S. and Lin, W., 2019. Restoration of long-term monoculture degraded tea orchard by green and goat manures applications system. Sustainability 11: 1011; doi:10.3390/su11041011.

Kantar, M.B., Anderson, J.E., Lucht, S.A., Mercer, K., Bernau, V., Case, K.A., Le, N.C., Frederiksen, M.K., DeKeyser, H.C., Wong, Z-Z., Hastings, J.C., Baumler, D.J., 2016. Vitamin variation in capsicum spp. provides opportunities to improve nutritional value of human diets. PLoS ONE 11(8): e0161464. doi:10.1371/journal.pone.0161464 
Korsaeth A, Henriksena T.M., Bakken, L.R., 2002 Temporal changes in mineralization and immobilization of $\mathrm{N}$ during degradation of plant material: implications for the plant $\mathrm{N}$ supply and nitrogen losses Soil Biol. Biochem. 34: 789-99.

Mabuza, T.Z., Masarirambi, M.T., Nxumalo, K.A., and Wahome, P.K., 2019. Effects of different rates of cattle manure on growth, yield and quality of pepper (Capsicum annuum L.) in a sub-tropical environment of Eswatini (Swaziland). Asian Journal of Advances in Agricultural Research 11: 1-7.

Naramabuye, F.X. and Haynes, R.J., 2006 Short-term effects of three animal manures on soil $\mathrm{pH}$ and Al solubility AUST J SOIL RES 44: 515-521.

Olatunji, T.L. and Afolayan, A.J., 2018. The suitability of chili pepper (Capsicum annuum L.) for alleviating human micronutrient dietary deficiencies: A review. Food Science and Nutrition 6: 2239-2251

Pampuro N., Tebaldo V., Fabbri D., Calza P., Faga M.G., Cavallo E., 2017. Effect of organic fertilization on capsaicin content in trinidad scorpion (Capsicum chinese) peppers: preliminary results. Chemical Engineering Transactions, 58: 253-258.

Prasad, H., Sajwan, P., Kumari, M. and Solanki, S.P.S., 2017. Effect of organic manures and biofertilizer on plant growth, yield and quality of horticultural crop: A review. International Journal of Chemical Studies. 5: 217-221.

Reddy, G.C., Venkatachalapathi, V., Reddy, G.P.D., 3 and Hebbar, S.S., 2017. Study of different organic manure combination on growth and yield of chilli (Capsicum annuum L.). Plant Archives 17: 472-474.

Rehim, A., Khan, M., Imran, M., Bashir, M.A. Ul-Allah, S., Khan, M.N., and Hussain, M., 2020. Integrated use of farm manure and synthetic nitrogen fertilizer improves nitrogen use efficiency, yield and grain quality in wheat. Italian Journal of Agronomy 15:29-34.

Rudisill, M.A., Bordelon, B.P., Turco, R.F. and Hoagland, L.A., 2015. Sustaining Soil Quality in Intensively Managed High Tunnel Vegetable Production Systems: A Role for Green Manures and Chicken Litter. HortScience 50: 461-468.

Saida, M.D.N., 2019. Konsumsi dan neraca penyediaan-penggunaan cabai. Buletin Konsumsi Pangan 10 (1):46-54.

Widyanti, A. S. dan Susila, A. D., 2015. Rekomendasi pemupukan kalium pada budi daya cabai merah besar (Capscicum annuum L.) di inceptisols Dramaga. Journal Hortikultura Indonesia 6: 65-74.

Zhang, H., Yu1, X., Jin, Z., Zheng, W., Zhai, B. and Li, Z., 2017. Improving grain yield and water use efficiency of winter wheat through a combination of manure and chemical nitrogen fertilizer on the Loess plateau, China. Journal of Soil Science and Plant Nutrition 17: 461-474. 